\title{
HERMINIA NAGLEROWA JAKO AUTORKA I BOHATERKA WSPOMNIEŃ O PISARZACH
}

\author{
Anna WAL (Rzeszów)
}

\begin{abstract}
Sytuacja wspomnienia - jako takiego - wydaje się beznadziejna: żadna jego realizacja nie może liczyć na petna aprobate odbiorcy ([...] wspótczesnego aktowi wspominania). [...] Prawdziwy obraz postaci to taki, który dawatby poczucie równoczesności rozmaitych sfer jego przebywania, „kompleksów zainteresowañ”, postaw, mniemań, przyjaźni, „,grup odniesienia”, itp. Wspomnienia sq nieuleczalnie nieprawdziwe, ponieważ nie moga nigdy zbliżyć się do takiego obrazu. Redukuja one wielowymiarowa przestrzeń życiowq osobnika do jej poszczególnych wymiarów, a jego samego czyniq wiqzkq ,, aspektów”"
\end{abstract}

\section{Uwagi wstępne}

Obejmując refleksją piśmiennictwo wspomnieniowe Drugiej Emigracji chciałabym zwrócić uwagę na sporą grupę tekstów określanych mianem wspomnień o pisarzach. Wyróżnienie tej szczególnej odmiany wspomnień opiera się na kryterium tematycznym. Wspomnienie, jako jeden z podstawowych gatunków literatury dokumentu osobistego $^{2}$, ma bowiem wiele odmian. Wśród nich wyodrębnia się wspomnienia o cieka-

\footnotetext{
${ }^{1}$ J. Sławiński, Czas wspomnień, [w:] tegoż, Próby teoretycznoliterackie, Warszawa 1992, s. 161.

${ }^{2}$ Przyjmuję ustalenia Małgorzaty Czermińskiej, która w XX-wiecznym pisarstwie osobistym wyróżniła cztery gatunki: pamiętnik, autobiografię, wspomnienie i dziennik; por.: M. Czermińska, Autobiograficzne formy, [w:] Stownik literatury polskiej XX wieku, red. A. Brodzka, M. Puchalska, M. Semczuk, A. Sobolewska, E. Szary-Matywiecka, Wrocław 1995, s. 49; taż, Autobiograficzny trójkq̨t. Świadectwo, wyznanie, wyzwanie, Kraków 2000, s. 14 i następne.
} 
wych, wybitnych ludziach ${ }^{3}$. Cechą charakterystyczną tekstów jest to, że skupiają się wokół jednej centralnej osoby. Zawężając kategorię ciekawych ludzi do pisarzy, a ci ciągle (chociaż we współczesnej kulturze chyba w nieco mniejszym stopniu) należą do ludzi, których, zdaniem Zdzisława Czermańskiego, ,,jesteśmy ogromnie ciekawi, chcielibyśmy ich widzieć, słyszeć i dużo o nich wiedzieć" ${ }^{4}$, otrzymujemy stosunkowo liczną grupę tekstów - wspomnień o pisarzach.

Popularność na wychodźstwie szkiców o pisarzach różnych generacji, a wśród nich także tych o charakterze wspomnieniowym, potwierdza omówienie tego rodzaju piśmiennictwa przez Józefa Bujnowskiego, zamieszczone w Literaturze polskiej na obczyźnie ${ }^{5}$ oraz pisany jako jego dopełnienie artykuł Eugeniusza Romiszewskiego Wzmożona fala wspomnień w literaturze emigracyjnej 1961-1976 ${ }^{6}$.

Nawet pobieżny ogląd piśmiennictwa wspomnieniowego poświęconego pisarzom pozwala zauważyć, że często autorami tekstów są ludzie pióra, a więc koledzy lub inne osoby ze środowiska artystycznego. Zatem pisarze występują wtedy w podwójnej roli jako autorzy wspomnień i jako ich bohaterowie. Przy czym bohaterami są zarówno jako pierwszoplanowe postaci, gdy inni piszą o nich, lub gdy wspominając innych, równocześnie piszą także o sobie, pozostając najczęściej gdzieś w tle, gdyż wspomnienia to także książki autobiograficzne, w szerokim, ponadgatunkowym znaczeniu tego terminu? ${ }^{7}$.

W takiej właśnie podwójnej roli, jako wspominająca i wspominana, wystąpiła Herminia Naglerowa ${ }^{8}$.

W pierwszej części artykułu jej poświęconego przedmiotem moich zainteresowań jest tom tejże autorki, Wspomnienia o pisarzach, składający się z dziewięciu szkiców. Analizując go skoncentruję się przede wszystkim na tych cechach tekstów, które uwarunkowane są przynależnością gatunkową . Ze względu na konwencję pisarstwa wspomnieniowego istotne jest określenie sytuacji narracyjnej, dystansu narratora wobec prezentowanego świata, a w konsekwencji stosunku do „ludzi i czasów minionych”. Uwagi domaga się także sposób przedstawiania głównych bohaterów poszczególnych wspomnień oraz strategia prezentacji ,ja" autorskiego, a więc wskazanie roli autora w narracji, którą możemy określić jako autobiograficzną.

Pominę natomiast ciekawą, nawiasem mówiąc, dla historyków literatury wartość faktograficzną Wspomnień o pisarzach, ponieważ wymagałoby to innego typu badań,

${ }^{3}$ Por.: E. Romiszewski, Wzmożona fala wspomnień w literaturze emigracyjnej 1961-1976, Pamiętnik Literacki (Londyn) 1978 t. 2, s. 78.

${ }^{4}$ Z. Czermański, Lechoń, [w:] tegoż, Kolorowi ludzie, Londyn 1966, s. 286.

${ }^{5}$ Informacje o interesujących mnie wspomnieniach, o pisarzach są rozproszone: J. Bujnowski, Esej oraz tenże, Szkic literacki i krytyka artystyczna, [w:] Literatura polska na obczyźnie 1940-1960, praca zbiorowa pod red. T. Terleckiego, t. 1, Londyn 1964.

${ }^{6}$ E. Romiszewski, Wzmożona fala..., s. 78-79.

${ }^{7}$ Por.: D. Szajnert, Autobiografia, [w:] Stownik rodzajów i gatunków literackich, red. G. Gazda, Kraków 2006, s. 52.

${ }^{8}$ Analogiczna sytuacja dotyczyła wielu pisarzy, na przykład Kazimierza Wierzyńskiego, który był autorem szkiców wspomnieniowych o pisarzach (Wspomnienie o Pasternaku, Andrzej Bobkowski, O Leopoldzie Staffie), które zamieścił w rozdziale książki Cygańskim wozem (Londyn 1966), a inne opublikowane były, np. w Szkicach i portretach literackich (Kornel Makuszyń$s k i-w 10$ rocznice zgonu). Również sam poeta był bohaterem wspomnień, o czym świadczy wydawnictwo zbiorowe jemu poświęcone - Przebity świattem, Londyn 1969.

${ }^{9}$ Inspiracją dla mnie była praca Reginy Lubas-Bartoszyńskiej, Style wypowiedzi pamiętnikarskiej, Kraków 1983. 
konfrontacji ze źródłami pozapamiętnikarskimi, sprawdzania wiarygodności faktów, które w tego typu piśmiennictwie często balansują, jak to określił niegdyś Edward Kozikowski ,między prawdą a plotką"10.

Charakterystyczne, że nieufność wobec warstwy faktograficznej wspomnień, w metatekstowych komentarzach, deklarowała sama Herminia Naglerowa. Porównując wspominania do procesu twórczego, zanegowała zarazem wartość dokumentalną tego typu tekstów. Oto fragment będący wyrazem jej poglądów:

Nie łatwo jest podołać wydarzeniom, nawet osobiście przeżywanym w tamtych latach względnej równowagi wszystkich czynników ludzkiego bytowania — konstatuje autorka Wspomnień o pisarzach. — Za bliskie, za odlegle, za żywe, umarłe? Próbuję to sobie wytłumaczyć tak istotną dla wspomnienia przekora, która albo nieświadomie przeobraża, albo jest rozmyślnym odstępstwem od rzeczywistości. W obu wypadkach odtwarzanie ma coś z procesu twórczego i tym samym przestaje być dokumentem (s. 85) ${ }^{11}$.

Herminia Naglerowa dała wyraz świadomości ograniczeń, jakim podlega autor wspomnień, ulegając chociażby sile takich uczuć, jak nostalgia, wzruszenie, które modyfikują obraz dawnych czasów i ludzi. Dlatego kategoria pamięci, jakże ważna w piśmiennictwie wspomnieniowym, zostaje określona przez nią mianem ,przeobrażonej” (s. 86). Ten rodzaj odautorskich komentarzy można odczytywać jako swego rodzaju próbę asekuracji przed ewentualnymi zarzutami dotyczącymi adekwatności wizerunków wspominanych osób i odtwarzanych zdarzeń.

Ostatnią część mojego szkicu poświęcę wspomnieniom innych pisarzy o Herminii Naglerowej, koncentrując się na analizie tekstów i zawartego w nich wizerunku autorki Kazachstańskich nocy.

\section{Herminii Naglerowej Wspomnienia o pisarzach}

1 .

Książka Herminii Naglerowej Wspomnienia o pisarzach wydana została w londyńskiej Oficynie Poetów i Malarzy w 1960 roku, a więc trzy lata po śmierci autorki. Przygotowała ją do druku Maria Danilewiczowa. To połączenie rzetelności i profesjonalizmu Danilewiczowej oraz wydawców zaowocowało pozycją, której walory edytorskie zwróciły uwagę recenzentów, podobnie jak cała książka, która została życzliwie przyjęta $^{12}$. Zawiera ona dziewięć szkiców wspomnieniowych, stosunkowo niewielkich rozmiarów, niemniej o pisarzach wybitnych, takich jak: Wacław Sieroszewski (Sybirak - legionista - prezes), Stefan Żeromski (Cierpienia i zwycięstwa pisarza), Andrzej Strug, (Bezkompromisowy), Wacław Berent (Pisat nie spieszac się), Karol Irzykowski (Autor „Pałuby”), Bolesław Leśmian (Przyjaciel z innego wymiaru), Maria Wielopolska (Człowiek znika bez śladu), Juliusz Kaden-Bandrowski (Czy nie za szybko zapomniany), Maria Dąbrowska (Z rodu polskich humanitarystów).

${ }^{10}$ E. Kozikowski, Między prawdq a plotkq. Wspomnienia o ludziach $i$ czasach minionych, Kraków 1961, s. 5.

${ }^{11}$ Wszystkie cytaty pochodzace z książki Herminii Naglerowej, Wspomnienia o pisarzach, przygotowała do druku M. Danilewiczowa, Londyn 1960; kolejne cytaty lokalizuję w tekście poprzez podanie numeru strony w nawiasach okragłych.

12 Por.: K. Wierzyński, Wspomnienia Herminii Naglerowej o pisarzach dwudziestolecia, [w:] tegoż, Szkice i portrety literackie, zebrał i posł. opatrzył P. Kądziela, Warszawa 1990, s. 139 (przedruk z: Dziennik Polski i Dziennik Żołnierza 1961 nr 12); Z. Kozarynowa, Naglerowa o pisarzach, Wiadomości $1960 \mathrm{nr}$ 48, s. 3. 
Wspomnienia o pisarzach skomponowane zostały, jak wiele tego typu publikacji, według zasady, którą określa się jako „galeria portretów”. Taki charakter mają także wydane w tym samym roku, co książka Naglerowej, Ludzie, ksiażki i kulisy (Londyn 1960) Tymona Terleckiego lub nieco późniejsze, bo z 1968 roku, wspomnienia Tadeusza Nowakowskiego Aleja dobrych znajomych (Londyn 1968), czy Stefanii Kossowskiej Galeria przodków (Warszawa 1991). Przy czym w tego typu wydawnictwach najczęściej pisarze nie są jedynymi wspominanymi, jak to się dzieje w książce Naglerowej, pojawiają się obok portretów, na przykład członków środowisk artystycznych, jak we wspomnieniach Tymona Terleckiego lub członków rodziny, nauczycieli, jak u Tadeusza Nowakowskiego.

Na tom Wspomnień o pisarzach złożyły się szkice „skreślone w pierwszej redakcji — czytamy w nocie wydawniczej — w latach 1944-1946, poddane następnie przeróbkom około r. 1951-[195]2""13. Drukowane były w prasie ukazującej się na obczyźnie (we Włoszech) w „Dzienniku Żołnierza APW” , „Na Szlaku Kresowej”, w „Orle Białym”, a po drugiej redakcji w czasopismach „Nowy Świat” (Nowy Jork), „Ostatnie Wiadomości” (Mannheim), ,Robotnik” (Londyn) ${ }^{14}$.

To, że znaczna część szkiców tworzących tom Wspomnień o pisarzach powstawała w burzliwym zarówno w biografii pisarki ${ }^{15}$, jak i dziejach Europy okresie, a więc u schyłku II wojny światowej lub niedługo po jej zakończeniu wydaje się mieć decydujące znaczenie, przejawiające się w spojrzeniu na wspominany miniony czas i ludzi.

Należy podkreślić, że w kompozycji książki, ale i pojedynczych tekstów niezwykle ważną rolę odgrywają dwie kategorie: czas i przestrzeń. Wspomnienia zasadniczo obejmują dwudziestolecie międzywojenne. Chociaż bohaterami są w większości pisarze, tzw. „łącznicy”, dwóch pokoleń i epok, Młodej Polski i dwudziestolecia (czyli jednako do obu przynależący ${ }^{16}$ ), niemniej Naglerowa koncentruje się na ich działaniach literackich, fragmentach biografii, pozycji w środowisku właśnie w okresie międzywojennym, w okresie Polski „odrodzonej”, dlatego na przykład o Sieroszewskim pisze określając jego dorobek mianem „spuścizny”, a o Strugu, Berencie jako o tych, którzy odsunęli się od głównych nurtów życia literackiego.

Wspomnienia nie tylko dotyczą określonego czasu, ale wpisane zostały w konkretną przestrzeń Warszawy, miasta z którym wówczas związana była wspominająca narratorka i prezentowani przez nią pisarze. Tym samym Naglerowa dopisuje kolejne stronice do istniejących obrazów życia literackiego, towarzyskiego, obyczajowego międzywojennej Warszawy ${ }^{17}$. Utrwala pamięć takich miejsc jak księgarnia Mortkowiczów,

${ }^{13}$ Nota wydawnicza, [w:] H. Naglerowa, Wspomnienia o pisarzach, s. 95.

14 Tamże, s. 95-96.

${ }^{15}$ Przypomnijmy, że w latach 1944-1947 Naglerowa przebywała we Włoszech, gdzie dotarła, jak wielu byłych więźniów sowieckich łagrów, wraz z armią dowodzoną przez gen. Andersa, a więc w 1941 r. wstąpiła w szeregi Pomocniczej Służby Kobiet przy Armii Polskiej na Wschodzie, a następnie przeszła szlak bojowy wraz z 2. Korpusem (Bliski Wschód, Egipt, Włochy). W 1947 r. Naglerowa opuściła Włochy i zamieszkała w Londynie, gdzie przebywała do końca życia.

${ }^{16}$ Por.: A. Hutnikiewicz, Młoda Polska, Warszawa 1999, s. 138.

17 Józef Olejniczak wspomnienia mające za swój przedmiot życie artystyczne i literackie międzywojennej Warszawy, Krakowa, Lwowa, czy Wilna wyróżnia jako odrębną grupe ,prozy «wspominkarskiej»”; por.: J. Olejniczak, Proza „wspominkarska”, [w:] Literatura emigracyjna 1939-1989, red. J. Olejniczak, Katowice 1996, t. 2, s. 135. Wcześniej o „geografii Polski” wyłaniającej się ze wspomnień pisała Maria Danilewicz Zielińska w Szkicach o literaturze emigracyjnej, Wrocław 1992, w rozdziale Wśród pamiętników i „,wspominków”, s. 297-299. 
rozsławiona „Ziemiańska” wraz z jej bywalcami. Odnotować można jedynie rzadkie wykroczenia poza wyznaczone ramy czasowe i przestrzenne.

Międzywojenna Warszawa obecna we wspomnieniach skłania do dygresji dotyczącej biografii autorki. Warto bowiem przypomnieć, że lata 1919-1939 to okres w jej życiu, który moglibyśmy nazwać warszawskim. W 1919 roku przyszła pisarka przeniosła się ze Lwowa do stolicy, gdzie zamieszkała wraz z mężem, doktorem prawa, Leonem Naglerem, byłym legionistą, pracującym w Warszawie w Policji Państwowej na stanowisku zastępcy komendanta $^{18}$. Jest to także niezwykle ważny okres $\mathrm{w}$ jej literackiej karierze, czas debiutu książkowego, najpierw poetyckiego (1921), a później prozatorskiego (1924) i kolejno wydawanych książek, z których ostatnią byli Krauzowie $i$ inni $^{19}$. To w Warszawie miały miejsce istotne wybory artystyczne, na który wpływ wywarli między innymi pisarze prezentowani przez Naglerową w analizowanych wspomnieniach.

Zwraca uwage stosunek autorki do dwudziestolecia międzywojennego, jako epoki już zamkniętej, której kres wyznaczyła wojna. Siebie samą określa „niemal korzeniami wyrwaną z dwudziestolecia" (s. 76).

Wszystkie teksty, poza ostatnim o Marii Dąbrowskiej, poświęcone były pisarzom nieżyjącym, zmarłym bądź jeszcze przed wybuchem II wojny światowej, jak Stefan Żeromski (1925), Andrzej Strug (1937), Bolesław Leśmian (1937) lub w czasie trwania działań wojennych. Wskutek odniesionych ran życie stracili Karol Irzykowski (1944), Juliusz Kaden-Bandrowski (1944), natomiast Maria Jehanne Wielopolska zaginęła w Rosji (1940), a w 1945 roku zmarł, sędziwy już wówczas, Wacław Sieroszewski. Pamięć tragicznych skutków wojny, przedwczesnych śmierci, wielu dramatów ludzkich odciska swe piętno na tonacji wspomnień, decyduje o obecności motywów funeralnych. Szkice o zmarłych w czasie wojny pisarzach, w pogrzebie których pisarka nie mogła uczestniczyć, zawierają słowa pożegnania. Stąd szczególna funkcja — oddania hołdu pamięci zmarłym, poległym, jaką swoim tekstom przypisuje Naglerowa, a niekiedy nawet symbolicznego grobu, jak w przypadku szkicu Człowiek znika bez śladu o pisarce, publicystce, a zarazem sąsiadce z warszawskiego mieszkania na Brzozowej, Marii Wielopolskiej. Czytamy w nim: „Miałkie słowa wspomnień usiłują sypać im mogiły. Mowa, słowo pragnie spełnić zadanie rodzinnej ziemi, otulić, ogarnać, zachować w ściszonym trwaniu" (s. 74). Zdania te nabierają szczególnego znaczenia, gdy uświadamiamy sobie, że w Rosji zaginął „,bez śladu” mąż pisarki, aresztowany jesienią 1939 roku przez NKWD.

Wspomnienie o Marii Wielopolskiej to w zamyśle autorki także dopisane stronice do publikacji o stratach kultury polskiej ${ }^{20}$, natomiast w szkicu o Kadenie-Bandrowskim, pod jakże wymownym tytułem: Czy nie za szybko zapomniany?, dominuje chęć przypomnienia czytelnikom rangi twórcy, zdaniem Naglerowej zaraz po wojnie niedocenianego.

Poza tonacją żalu ,za bliskimi, za przyjaciółmi, których śmierć była nieludzko tragiczna", wspomnienia te dotyczą również czasów szczęśliwych dla autorki. Akcen-

\footnotetext{
${ }^{18}$ O roli Leona Naglera, zajmowanych stanowiskach w Policji Państwowej pisze A. Misiuk, Policja Państwowa 1919-1939. Powstanie, organizacja, kierunki działania, Warszawa 1996, s. 155, 186, 191-193, 313, 324.

${ }^{19}$ H. Naglerowa, Krauzowie i inni: powieść w trzech tomach, Rzym 1946.

${ }^{20}$ H. Naglerowa zwraca uwagę, że w Stratach kultury polskiej 1939-1944 (t. 1-2, oprac. [J. Hulewicz] A. Ordęga, T. Terlecki, Glasgow 1945), postać Marii Wielopolskiej została pominięta; por.: H. Naglerowa, Cztowiek znika bez śladu, [w:] tejże, Wspomnienia o pisarzach..., s. 65.
} 
tuje to w metatekstowych uwagach, jak ta: „Drobne, błahe, śmieszne wspomnienia napierają się, żeby zasłonić to ciemne i groźne jakim jest kres" (s. 84). W innym miejscu przyznaje:

Ale w tymże momencie nadpływa uśmiech należny tamtym dniom, miłym od wspomnień: wzajemne odwiedziny, nasze zaciszne domy, przyjęcia nawet może wystawne, przyjazne i pobudzające rozmowy, a niechby i spory, gniewy, wzajemne urazy (s. 83).

Nie dziwi więc, że ów czas warszawski, po latach na emigracji, pisarka nazwała okresem „dwudziestu lat czaru i rozczarowań” (s. 10).

2.

Lektura wspomnień każdego rodzaju, skłania do stawiania pytań o selekcję materiału, o strategię wspominania. W książce tego typu, jak Wspomnienia o pisarzach Naglerowej, najważniejsze wydają się być zagadnienia związane ze sposobem przedstawienia pierwszoplanowych bohaterów szkiców. Kazimierz Wierzyński recenzując tom pisat:

Są to krótkie impresje oparte najczęściej na motywie jakiegoś spotkania i rozwijające się z tego tematu jak ze szpulki. Dziesięć stron wystarczy Naglerowej na opowiedzenie anegdoty, opis wyglądu i kilku rysów charakterystycznych omawianego pisarza ${ }^{21}$.

To ujęcie wymaga pewnych uzupełnień. Warto zauważyć, że nie są to ulotne wspomnienia, osnute na jednym spotkaniu. Choć są niezbyt obszerne, widoczne jest dążenie autorki do swego rodzaju syntezy, a wiec skrótowego ujęcia całości dokonań twórcy. Przykładem chociażby pierwsze wspomnienie o Wacławie Sieroszewskim, którego biografię i twórczość literacką zamknęła pisarka w lapidarnej formule Sybirak - Legionista - Prezes, przedstawiając go w tych trzech rolach życiowych. Szkice o pisarzach nie są konstruowane na wzór rozbudowanych haseł encyklopedycznych, mają wiele cech portretu literackiego ${ }^{22}$. By w tak krótkich tekstach ukazać wieloaspektowo sylwetki pisarzy stosuje łącznie dwie perspektywy, nazwijmy je „bliską” i „daleką”. W analogii do języka filmu moglibyśmy powiedzieć, że autorka Wspomnień o pisarzach posługuje się zbliżeniem, wykorzystując jeden ze stałych elementów szkiców wspomnieniowych, a mianowicie motyw bezpośredniego spotkania z danym pisarzem, co pozwala zmniejszyć dystans do portretowanej postaci, opisać jej wygląd zewnętrzny. Naglerowa przywiązuje dużą wagę do fizjonomii, jest uwrażliwiona na szczegół. Każdy z pisarzy otrzymał swój słowem kreślony portret. „Paszportowe rysopisy” autorka zwykła uzupełniać detalami i elementami, które nadawały jakieś szczególne piętno wyglądowi zewnętrznemu, na przykład niekiedy jest to, jak w przypadku Berenta, „,kolor cery tak czerwony, jak gdyby z całej twarzy zdarto naskórek” (s. 34), a innym razem zwraca uwagę na piękny profil Struga, nieprzystający do jego skromnej postury.

„Zbliżenia” to także uszczegółowione opisy konkretnych sytuacji, zachowań, gestów utrwalonych w pamięci wspominającej, w myśl poglądu pisarki, że „ludzie są wyraźni w jakimś epizodzie swojego życia, choćby tylko uchwyconym przelotnie i przypadkowo" (s. 15). Przywoływane i odtwarzane epizody bywają różnej rangi, niemniej dzięki nim autorce niejednokrotnie udaje się odsłonić nieznane oblicza portretowanych i uczynić wyłom w powszechnie obowiązującym wizerunku. Przykładem

\footnotetext{
${ }^{21}$ K. Wierzyński, Wspomnienia Herminii Naglerowej..., s. 139.

${ }^{22}$ Por.: J. Sławiński, Portret literacki, [w:] Słownik terminów literackich, red. J. Sławiński, Wrocław 1988, s. 377.
} 
chociażby wspomnienie o Irzykowskim i opis dwóch sytuacji. Jednej w teatrze, gdy autor Pałuby ukradkiem strząsa z oczu łzy podczas melodramatycznej sztuki i drugiej, także ukazującej łzy wzruszenia, jednak w okolicznościach o wiele poważniejszych, bo po wystąpieniu domagającym się wyjaśnienia sprawy Stanisława Brzozowskiego, jego współpracy z rosyjską ochraną. Relacje stanowią przeciwwagę dla wyeksponowanych wcześniej cech Irzykowskiego - krytyka i pamflecisty, zajadłego, zapalczywego, nie pozbawionego złośliwości, można by przypuszczać człowieka oschłego, nieskłonnego do wzruszeń.

Eksponowanie sprzeczności i kontrastów w wizerunkach pisarzy czyni postaci dynamicznymi, pozwala przynajmniej częściowo oddać skomplikowaną naturę ludzką, jakże trudną do ujęcia w jakiekolwiek schematy.

Naglerowa, obok omówionych ,zbliżeń”, „kreując” wizerunki współczesnych sobie, charakteryzując ich twórczość, postawy, formułując oceny sięga także po sądy natury ogólnej, odwołuje się do opinii innych. Dzięki takiej poetyce wspomnień, połączeniu różnych dystansów, które się dopełniają, pisarce udaje się w skrótowym ujęciu przedstawić istotne w biografii portretowanych osiągnięcia literackie, oczywiście bez pogłębionych interpretacji, a ich samych jako postaci barwne, pełnokrwiste, dynamiczne. Służą temu także przytaczane dykteryjki i anegdoty, jak chociażby te o szczególnej przyjaźni, jaka łączyła dwie skrajnie różne indywidualności: Bolesława Leśmiana i Franciszka Fiszera, znaną i malowniczą postać życia towarzyskiego międzywojennej stolicy, którego celnie pisarka określiła mianem „konesera wszystkiego co daje życie” (s. 59), a inny pamiętnikarz epoki, Juliusz Sakowski, mówił o nim „Wolter i Gargantua w jednej osobie"23.

Niemniej styl Wspomnień o pisarzach daleki jest od gawędziarstwa, które, jak trafnie zauważyła Zofia Kozarynowa, usprawiedliwiałby i wiek autorki, i odmiana gatunkowa. U Naglerowej proces jest odwrotny. „Z latami dochodzi do zrozumienia wagi i wartości słowa - konstatuje recenzentka — gospodaruje nim oszczędnie i z tym mistrzostwem, którego rezultatem jest prostota doskonała"24.

Konwencja wspomnieniowa pozwalała na swobodę i dowolność w doborze elementów budujących portrety, które najczęściej są różnorodne, jak ich bohaterowie, do których pisarka odnajduje, tutaj posłużmy się terminem Reginy Lubas-Bartoszyńskiej, odmienne „klucze interpretacyjne” (spośród tak tradycyjnych jak biografizm, psychologizm, formalizm $)^{25}$, by wydobyć cechy najbardziej charakterystyczne, wyróżniające każdego z pisarzy. Ową różnorodność „kluczy interpretacyjnych” obserwujemy nie tylko w odniesieniu do poszczególnych postaci, ale także w obrębie jednego wspomnienia. Potwierdzeniem tej tezy jest szkic poświęcony Karolowi Irzykowskiemu.

Pisarka, wykorzystując zdobycze dwudziestowiecznej psychologii (między innymi psychoanalizy), poddała analizie osobowość twórczą autora Pałuby, powieści wyprzedzającej swe czasy. Po zaprezentowaniu dorobku literackiego Irzykowskiego prozaika, ale także krytyka i dramaturga, skoncentrowała się na opisie faz przeobrażeń w większym stopniu człowieka niż pisarza. Nakreśliła etapy jego drogi życiowej prowadzącej od socjalizmu aż do regularnych pobytów w Laskach u księdza Władysława Korniłowicza.

W szkicu poświęconym Irzykowskiemu autorka Wspomnień o pisarzach nie pominęła także sfery prywatności. Starała się bowiem przybliżyć czytelnikowi dwa, często nieprzystające do siebie obszary życia i działalności pisarza, a mianowicie twórczość

\footnotetext{
${ }^{23}$ J. Sakowski, Asy i damy. Portrety z pamięci, Paryż [1962], s. 119.

${ }^{24}$ Z. Kozarynowa, Naglerowa o pisarzach...

${ }^{25}$ R. Lubas-Bartoszyńska, Style wypowiedzi..., s. 163.
} 
literacką i codzienną egzystencję. Przeciwstawiła nowatora w zakresie koncepcji literatury tradycjonaliście w sprawach obyczajowych i wychowania dzieci. W tych ostatnich bowiem nie uznawał żadnego nowatorstwa, w myśl zasady: „tak ma być, jak za prababek bywało w pięknym mieście Brzeżany" (s. 49-50).

Sposób portretowania stosowany przez autorkę Wspomnień o pisarzach wysoko oceniła recenzująca tom Zofia Kozarynowa. Ujęła to następująco:

Z właściwą pisarzom wysokiej klasy umiejętnością wyboru szczegółów Naglerowa wydobywa z każdej z dziewięciu wspominanych postaci rysy nowe, dodatnie, ujemne, lub po prostu inne, nie zbanalizowane rozgłosem ${ }^{26}$.

W piśmiennictwie wspomnieniowym niezwykle ważna jest posiadana wiedza o opisywanych osobach, faktach, oczywiście nie tylko słownikowa, encyklopedyczna, ale ta będąca konsekwencją zarówno więzi towarzyskich, jak i duchowych. Stąd portrety osób, z którymi pisarka związana była bliżej, a więc Leśmiana, Irzykowskiego, Marii Wielopolskiej, Juliusza Kadena-Bandrowskiego są bogatsze w szczegóły, ciekawsze.

Uwzględniając ostatnie ze wskazanych kryteriów możemy mówić o pisarzach portretowanych bardziej powierzchownie, jak szanowani i uznawani, choć emocjonalnie raczej obojętni, Strug i Berent. Wspomnienia o nich — stosunkowo krótkie, bo liczące zaledwie ok. sześciu stron — „uchylają się przed bezpośredniością”, niemniej i tu odnajdujemy „ciepłe” akcenty. W przypadku Struga autorka eksponuje jego pracowitość i ideową bezkompromisowość. Natomiast we wspomnieniu o Berencie jest to zachwyt wyrażony dla autora Ż̇ywch kamieni, ,książki aż nazbyt pięknej” (s. 33).

Pomiędzy tymi dwoma grupami usytuować można portrety nauczycieli i mistrzów młodości pisarki, którymi są Wacław Sieroszewski i Stefan Żeromski. Tym dwóm pisarzom, Sieroszewskiemu, a jeszcze w większym stopniu Żeromskiemu, Naglerowa przypisała istotną rolę w kształtowaniu własnej wyobraźni i świadomości, jak i świadomości swojego pokolenia. Autor Popiołów obdarzony został mianem „Wielkiego, Uwielbianego" (s. 18). Mimo tak bezpośrednio wyrażonego uznania i podziwu dla Żeromskiego, sam szkic wspomnieniowy nie należy do najlepszych w tomie.

W kontekście zależności literackich niezwykle ciekawe wydaje się wspomnienie o Kadenie-Bandrowskim, gdyż Herminię Naglerową zwykło się zaliczać do kręgu „kadenistów”. Sama pisarka, nie zaprzecza, iż w okresie poszukiwań artystycznych, prozaik wywarł na nią pewien wpływ. Problem ten przedstawia za pomoca anegdotycznego opisu sytuacji, wspominając przyjęcie, podczas którego — tu zacytujmy:

Juliusz z diabelskim uśmiechem oświadcza:

- Ze mnie się wywodzicie i ty, i Kuncewiczowa, i nawet ta dziwożyna Szelburg.

Nie Nałkowska jest waszą patronessą, tylko ja, który z polskiej prozy zrobiłem to, co Słowacki z poezji! - i dalej pisarka komentuje - Krzyczał tak, unosząc się na palcach, a my niby to skromnie i pokornie zaprzeczałyśmy, aby nie był tak pewny siebie. Potem, gdy już każda z nas wygrodziła sobie własne miejsce w pisarstwie, machnął na nas ręką, może lekceważąco, może niechętnie (s. 83).

Uwagę czytelnika zwraca także szkic poświęcony Marii Dąbrowskiej, jedynej żyjącej wówczas pisarki, spośród wspominanych przez Herminię Naglerową. Zainteresowanie jej osobą można wyjaśnić wykorzystując obecność we Wspomnieniach o pisarzach pewnego wątku myślowego, do którego autorka kilkakrotnie powraca. Dotyczy on skłonności krytyki do łączenia pisarzy w pary. Według Herminii Naglerowej są to zabiegi chybione, opierające się na równoczesności ich życia, a nie są uzasadnione

${ }^{26}$ Z. Kozarynowa, Naglerowa o pisarzach... 
wspólnotą ideową twórczości. Można by przypuszczać, że sąd ten dotyczy także sytuacji, w jakiej znalazły się obydwie pisarki, chociaż Naglerowa nie formułuje tego wprost. Warto przypomnieć, że sagę rodu Krauzów porównywano z opowieścią o Niechcicach Marii Dąbrowskiej ${ }^{27}$.

Naglerowa nie analizuje twórczości literackiej, talentu autorki Nocy $i$ dni, lecz usiłuje dokonać wnikliwej oceny jej osobowości, kultury intelektualnej i duchowej, dyscypliny myślii ${ }^{28}$. Konsekwencją tych analiz jest zaliczenie Dąbrowskiej do grona polskich humanitarystów, wierzących w człowieka, w sens rzetelnej, zarówno codziennej, jak i twórczej pracy, która stanowi podstawę do tworzenia kultury świata. Ów ród humanitarystów wywodzi pisarka od Andrzeja Frycza Modrzewskiego, Stanisława Konarskiego, Stanisława Staszica, poprzez Elizę Orzeszkową, aż do Edwarda Abramowskiego, któremu Dąbrowska wiele zawdzięczała. Wyjątkowość tego wspomnienia polega także na tym, że pisarka zawarła w nim swoje credo pisarskie, określając zarazem to, co różniło ją i Dąbrowską. Ujęła to następująco:

Maria Dą̧browska wierzy, czy też chce aby tak było, że człowiek w każdej rzeczy może znaleźć coś dobrego. Ja - nieco inaczej: wierzę, czy też chcę wierzyć, że człowiek musi dobro wyzwolić spod złogów zła. (s. 94)

Analizując Wspomnienia o pisarzach nie sposób nie zauważyć, że Naglerowa należy do osób powściągliwych, pozbawionych złośliwości w formułowaniu sądów i wyrażaniu opinii o innych, co nie oznacza, że brak jej krytycyzmu. W szkicu o Kadenie-Bandrowskim obok podziwu dla jego pracowitości i pisarstwa zauważamy także elementy krytyki, jawnej ironii obnażającej zachowania wynikające z ułomności charakteru, przede wszystkim egocentryzmu, pychy. Odwołując się do konceptu Tadeusza Nowakowskiego, który uważał, że opisywanie znajomych ma zawsze coś z przewodu sądowego, moglibyśmy stwierdzić, że autorka Wspomnień o pisarzach chętniej „występuje w roli świadka obrony niż oskarżenia" ${ }^{, 29}$. Na ową wyrozumiałość, złagodzenie sądów wpłynął zapewne, właściwy wspominającym, sentyment do przeszłości, tym bardziej zrozumiały w przypadku Naglerowej, bo dotyczył okresu między wojnami, a więc czasu stabilizacji, czasu, gdy osiągnęła pełnię sił życiowych i twórczych. Pisarka jest świadoma, że „kosmetyka wspomnień” jest funkcją przemijania, co wielokrotnie podkreśla za pomocą formuł językowych, akcentujących upływ czasu, na przykład: „Dziś jednak, gdy przypominam sobie te wzajemne zjadliwości...” (s. 81), czy w innym miejscu: „Teraz dopiero, kiedy go już nie ma, kiedy rozpięło się nad nim milczenie, doceniam jego działalność nie tylko pisarską" (s. 81).

Tym samym akcentuje fakt, że zasada interpretacyjna świata jest stanem świadomości ,ja” autorskiego w chwili pisania wspomnień, stanem różnym od świadomości ,ja" bohaterki z lat międzywojennych.

Poza upływem czasu, który łagodził oceny i sądy o innych i sobie, istotną była posiadana przez autorkę Wspomnień o pisarzach cecha, którą ceniła u Żeromskiego, który jej zdaniem ,ppotrafił podziwiać innego pisarza” (s. 19). Podobnie jak mistrz młodości, wydaje się, że umiała to czynić także Herminia Naglerowa, dostrzegająca

${ }^{27}$ Porównania te pojawiały się, np. w recenzjach Krauzów i innych pióra Jerzego Andrzejewskiego, U progu cyklu powieściowego, Prosto z mostu, $1936 \mathrm{nr}$ 14, s. 2; tenże, Dwie powieści. $O$,Ludziach z wosku” $i$,Krauzach $i$ innych”, Prosto z mostu 1936 nr 23, s. 7; K. Wyka, Mieszczańskie kariery, Tygodnik Ilustrowany $1936 \mathrm{nr} 37$.

${ }^{28}$ Por.: Z. Kozarynowa, Naglerowa o pisarzach...

${ }^{29}$ Por.: T. Nowakowski, Lady z polskiego Londynu, Więź 1991 nr 6, s. 120. 
u innych zawsze jakieś dobre cechy i wyraźnie nie znajdująca przyjemności w piętnowaniu bliźnich.

To, co z jednej strony jest zaletą, jest też i wadą wspomnień, bowiem czytelnik poznaje ,złagodzony” obraz środowiska literatów, w rzeczywistości rywalizujących ze sobą, skłóconych, wzajemnie się zwalczających. Nawet, jeżeli niektóre animozje istniejące w środowisku literatów pisarka odnotowuje, jak na przykład fakt istnienia, ,,antykadenowego stronnictwa" w Akademii Literatury, do którego należał również portretowany przez autorkę Irzykowski i Leśmian, nie wnika w ich szczegóły, jakby po latach, po wojennych doświadczeniach, wobec śmierci zainteresowanych, te fakty straciły na znaczeniu. Nie podejmuje także wątku różnic politycznych, a w gronie przez nią portretowanych byli pisarze mocno zabarwieni politycznie. Jedynie kreśląc portret Struga eksponuje jego ideową bezkompromisowość. Fakt, iż nie przyjął członkowstwa w Akademii Literatury budzi jej szacunek. We Wspomnieniach o pisarzach Herminii Naglerowej nie odnajdziemy także odzwierciedlenia walk politycznych, zantagonizowania stosunków społecznych, tego co wypełniało jakże burzliwą scenę polityczną i społeczną II Rzeczpospolitej. Niekiedy, jak na przykład do szkicu o Leśmianie, przenikają zaledwie enigmatyczne informacje o atmosferze politycznej, w tym konkretnym przypadku antysemickich atakach spod znaku ONR, OZON lat 30., według Edwarda Kozikowskiego boleśnie odczuwanych także przez pisarkę ${ }^{30}$.

\section{Autoportret}

Rozważając stosunek Naglerowej do portretowanych postaci dotknęliśmy istotnego zagadnienia, jakim jest manifestująca się we Wspomnieniach o pisarzach obecność ,ja" autorskiego.

Wspomnienia, podatne są - jak zauważa Małgorzata Czermińska ${ }^{31}$ — na dominację postawy świadka, niemniej druga z postaw autobiograficznych — postawa wyznania zaznacza się niezwykle mocno. Inny badacz — Janusz Sławiński — również zwrócił uwagę na szczególną obecność we wspomnieniach o zmarłych, świadków i uczestników ich życia. Zauważył on bowiem, że wspominający, „utrwalając — w pamiętnikach, gawędach wspomnieniowych, rozmowach — fakty biograficzne, z reguły mają na uwadze [...] swój własny w tych faktach udział, a któż nie pragnąłby pokazać się potomnym w możliwie korzystnym świetle i aureoli znaczenia?"32 — zapytuje Sławiński. Jednocześnie zwraca uwagę, że często konsekwencją takiej postawy jest odpowiednie podstylizowanie i podretuszowanie wizerunku bohatera wspomnień, bowiem ,jego odtwarzane — w relacjach — zachowania czy wypowiedzi muszą pozostać w zgodzie z autoportretem wspominającego",33.

W książce Naglerowej, zgodnie z konwencją gatunku, wspomnienia o innych łączą się ze wspomnieniami autorki o sobie, fragmenty jej biografii zostały w nie wpisane. Mimo że „ślady” ,ja” autorskiego są wyraźne, autorka nie przesłania opisywanych postaci, jej obecność w świetle sylwetek portretowanych pisarzy jest dyskretna ${ }^{34}$.

„Ja” autorskie prezentuje się $\mathrm{w}$ różnych rolach i wcieleniach. Po pierwsze, jako „opowiadająca”, a właściwie wspominająca po latach ludzi i wydarzenia, komentująca

\footnotetext{
${ }^{30}$ Por.: E. Kozikowski, Herminia Naglerowa, [w:] tegoż, Między prawdq a plotkq, s. 208-210.

${ }^{31}$ M. Czermińska, Autobiograficzny trójkqt..., s. 20.

${ }^{32}$ J. Sławiński, Czas wspomnień..., s. 160.

${ }^{33}$ Tamże, s. 160.

${ }^{34}$ Pisał o tym Józef Bujnowski, Szkic literacki i krytyka artystyczna, [w:] Literatura polska na obczyźnie..., t. 1, s. 331-332.
} 
reguły jakimi rządzą się wspomnienia, sam proces wspominania, związane $\mathrm{z}$ tym trudności, pułapki (o tej jej roli sporo już powiedziałam). Jednym słowem manifestacja podmiotowości piszącego realizuje się w sposób, który Ryszard Nycz określa jako „,autorską tematyzację czynności twórczych”35.

Po drugie, ,ja” autorskie przedstawia się także jako bohaterka wspomnień, kiedy, jakby na marginesie głównego wątku narracji o wydarzeniach z życia portretowanych pisarzy, opowiada o własnym losie, ujawnia fakty swojej biografii, niekiedy na przykład na zasadzie równoczesności zdarzeń. Częściej jednak wówczas, kiedy relacjonując różne sytuacje z życia prezentowanych postaci, osobiste spotkania ze wspominanymi pisarzami, opowiada także o sobie jako współuczestniczce, mniej lub bardziej aktywnej, o własnych stanach ducha, wrażeniach, przeżyciach, towarzyszących tym spotkaniom. W poszczególnych szkicach przedstawia się jako: współpracownica i początkująca recenzentka, „Gazety Porannej” i „Gazety Wieczornej” we Lwowie, pisarka, którą zwykło postrzegać się jako „kadenistkę” (Czy nie za szybko zapomniany?), jako autorka wydająca u Mortkowicza, działaczka zarządu warszawskiego ZZLP, redaktorka „Almanachu” Związku Pracy Obywatelskiej Kobiet (Z rodu polskich humanitarystów), uczestniczka życia kulturalnego Warszawy, a więc premier w Teatrze Polskim, koncertów w filharmonii (Pisat nie spieszac się).

Zaledwie marginalnie pojawia się sfera życia osobistego, epizodycznie towarzyszący pisarce mąż, kolejne mieszkania na Wilczej, Brzozowej (wraz z zapamiętanym widokiem na Wisłę) oraz informacje o życiu towarzyskim.

Mimo że zasadnicza część wspomnień, o czym już mówiłam, dotyczy okresu dwudziestolecia międzywojennego i pobytu pisarki w stolicy, na uwagę zasługuje kilkakrotnie akcentowane pochodzenie Naglerowej z Galicji Wschodniej. W opozycji do Warszawy w pamięci wspominającej zawsze pozostanie Lwów, miasto młodości, studiów uniwersyteckich, ale także miasto w sposób szczególny doświadczone w walkach o niepodległość.

Zbierając rozproszone w wielu szkicach informacje o ,ja” autorki możemy podjąć próbę rekonstrukcji jej losów, autoportretu, jaki wpisała we wspomnienia o innych. Otrzymujemy rodzaj ,sklejanki autobiograficznej”, niepełnej, z wieloma niewiadomymi. Współczesny czytelnik, a tym bardziej badacz literatury dokumentu osobistego, wyłaniający się ze wspomnień wizerunek pisarki traktuje jednak z nieufnością dotyczącą jego autentyczności, świadomy roli, jaką odgrywa element kreacji, nawet, jeśli pojawia się poza wiedzą autora ${ }^{36}$.

\section{Herminia Naglerowa we wspomnieniach innych}

Autoportret Naglerowej, wykreowany przez nią samą, warto skonfrontować z wizerunkiem, jaki przekazali we wspomnieniach o autorce Krauzów i innych koledzy po piórze. Są one rozproszone przede wszystkim w emigracyjnych czasopismach, nieliczne tylko ukazały się w kraju. Pierwsza fala wspomnień pojawiła się wkrótce po śmierci pisarki, która miała miejsce w Londynie 9 października 1957 roku. Wraz z dokonaniem się biografii autorki Kazachstańskich nocy, w określonym czasie historycznym, przeszła ona — w myśl koncepcji Janusza Sławińskiego — w „,czas wspo-

${ }^{35}$ Por.: R. Nycz, Osoba w nowoczesnej literaturze: ślady obecności, [w:] Osoba w literaturze i komunikacji literackiej, pod red. E. Balcerzana, W. Boleckiego, Warszawa 2000, s. 18 (,ZZ Dziejów Form Artystycznych w Literaturze Polskiej”, t. 81).

${ }^{36}$ Por.: tamże, s. 16-17. 
mnień”37. Według badacza „treść istotną tego czasu stanowią [...] świadectwa «prawdy» o zmarłym, dawane przez ludzi zaplątanych w jego koleje życiowe"38, dodajmy świadectwa, które charakteryzuje partykularny punkt widzenia.

Wspomnienia, które opublikowano wkrótce po śmierci pisarki, zgodnie z konwencją tego typu tekstów, skupiały się przede wszystkim na rekonstrukcji jej biografii, charakteryzowaniu twórczości literackiej oraz „służby społecznej” podejmowanej w kraju i na emigracji. Jednym słowem, wyliczając najważniejsze dokonania, koncentrowano się na przypomnieniu wielkości postaci.

Mimo zasadniczych podobieństw analizowanej grupy tekstów i ograniczonej liczby „aspektów” branych pod uwagę, ich odmienność opiera się na sposobie selekcji materiału przez poszczególnych uczestników, bądź świadków życia pisarki, różnorodności opisywanych relacji między nimi a zmarłą. Poza tym cechuje je duża rozpiętość tonacji uczuciowej od oschłej, oficjalnej po familiarną, intymną. Poszczególni autorzy nadają wspomnieniom własny indywidualny ton. Na przykład tekst Ludwika Rubla o charakterystycznym tytule $S p$. Herminia Naglerowa ${ }^{39}$ jest w zasadzie nekrologiem z elementami osobistego wspomnienia. Stąd jest niejednolity stylistycznie. Patos, współgrający z apologetycznym portretem pisarki, współistnieje obok rzeczowych, a zarazem pełnych ciepła fragmentów omawiających osobiste spotkania autora z rodaczką ze Lwowa na przełomie roku 1917-1918, czy późniejsze w czasie drugiej wojny światowej w Bagdadzie i te ostatnie w ,polskim” Londynie.

Funkcję nekrologów pełniły artykuły Wiesława Wohnouta. Jeden z nich, Herminia Naglerowa, drukował „Dziennik Polski i Dziennik Żołnierza”,40, a drugi O twórczości Herminii Naglerowej - „Orzeł Biały”41. Wohnout w dwóch różnych tekstach skoncentrował się na analizie twórczości literackiej autorki Krauzów i innych. Jako punkt wyjścia przyjął tezę, iż w twórczości pisarza odzwierciedla się duch epoki. Interpretował więc prozę Naglerowej, ale także jej postawę społeczną, działalność publicystyczną w kontekście epoki i prądów umysłowych, które ukształtowały artystkę. Artykuły zawierają wybrane informacje bibliograficzne i biograficzne. W zakresie tych ostatnich Wohnout poprzestał na wojennych i emigracyjnych losach autorki Ludzi sponiewieranych.

Natomiast Zofia Kozarynowa w szkicu Pani Herminia ${ }^{42}$, usiłowała spojrzeć na pisarkę, nakreślić jej portret i zrozumieć osobowość twórczą poprzez, czytaną już po wojnie, powieść Krauzowie i inni. Szkic ten, we fragmentach poświęconych analizie utworu, przełamuje skostniałe wzorce pośmiertnych wspomnień o pisarzach. Kozarynowa wysuwa tezę, że „klimat Krauzów $i$ innych był klimatem” autorki powieści, co stara się udowodnić. We wspomnieniu odnajdujemy ciekawe wątki z ostatniego okresu życia Naglerowej, a więc jej dziesięcioletniego pobytu w Londynie.

W kontekście wyżej omówionych szkiców wspomnieniowych drukowanych na łamach pism emigracyjnych, z którymi Naglerowa współpracowała, zwraca uwage krajowa publikacja Stefanii Podhorskiej-Okołów Wspomnienie o Herminii Naglero$w_{e j}{ }^{43}$. Przedwojenna redaktorka kobiecego tygodnika „Bluszcz” dokonała jakże okrojonej analizy twórczości literackiej autorki Krauzów i innych, poprzestając w zasadzie na

\footnotetext{
${ }^{37}$ J. Sławiński, Czas wspomnień..., s. 159.

${ }^{38}$ Tamże, s. 159.

${ }^{39}$ L. Rubel, Śp. Herminia Naglerowa, Orzeł Biały $1957 \mathrm{nr} 42$.

${ }^{40}$ W. Wohnout, Herminia Naglerowa, Dziennik Polski i Dziennik Żołnierza 1957 nr 238.

${ }^{41}$ Tenże, O twórczości Herminii Naglerowej, Orzeł Biały $1957 \mathrm{nr} 43$.

${ }^{42}$ Z. Kozarynowa, Pani Herminia, Wiadomości 1957 nr 48, s. 1.

${ }^{43}$ S. Podhorska-Okołów, Wspomnienie o Herminii Naglerowej, Twórczość 1957 nr 12, s. 173.
} 
tej ostatniej przedwojennej powieści z 1936 roku. Jak się domyślamy ze względów cenzuralnych Podhorska-Okołów pominęła pobyt Naglerowej w łagrach i teksty poświęcone tej tematyce, informując polskiego czytelnika jedynie o ,pracach organizacyjnych i redakcyjnych" pisarki na emigracji i poprzestając na wymienieniu tytułu, redagowanej przez nią książki Mickiewicz żywy i następnej z tej serii, Wyspiański żywy ${ }^{44}$.

Impulsem do powstania kolejnych wspomnień o Naglerowej było ukazanie się dziesięć lat po jej śmierci ostatniej, niedokończonej powieści Wierność życiu. Fakt ten pobudził do spisania wspomnień Mariana Czuchnowskiego, który opublikował szkic wspomnieniowy Profil $w$ złotych gałazkach ${ }^{45}$ oraz Janinę Surynową-Wyczółkowską, autorkę tekstu Ostatnia ksiażka Herminii ${ }^{46}$.

Szkic wspomnieniowy Mariana Czuchnowskiego wyróżnia zawarta w nim zwięzła charakterystyka twórczości autorki Ludzi sponiewieranych, wynikająca z chęci przypomnienia jej osiągnięć, przede wszystkim jako prozaika, oraz relacje z osobistych spotkań z Naglerową. Natomiast tekst Janiny Surynowej-Wyczółkowskiej, wbrew tytułowi $^{47}$, jest mozaiką, jaką tworza, przywoływane z pamięci, pojedyncze epizody ze wspólnych spotkań tych dwóch pisarek, ich wzajemnych relacji, zarówno w międzywojennej Warszawie, jak i podczas pobytu na emigracji.

Wspomnienia poświęcone Naglerowej odnajdziemy nie tylko rozproszone w prasie, ale także w książkach różnych autorów. Ukazywały się one na przestrzeni kilkudziesięciu lat. Wśród nich na szczególną uwagę zasługuje szkic Edwarda Kozikowskiego Herminia Naglerowa zamieszczony w Między prawda a plotka. Wspomnienia o ludziach i czasach minionych ${ }^{48}$, nota wspomnieniowa Marii Danilewicz Zielińskiej w książce tejże autorki Fado o moim życiu ${ }^{49}$. Naglerowa w pojedynczych epizodach pojawia się w książkach wspomnieniowych poświęconych innym osobom, na przykład u Tadeusza Nowakowskiego w Alei dobrych znajomych, w tekście O Stefanii Zahorskiej $^{50}$, ale i innym sprawom, na przykład $N a$ nieludzkiej ziemi Józefa Czapskiego ${ }^{51}$, czy miejscom — Krzysztof Głuchowski W polskim Londynie 1947-1970 ${ }^{52}$.

\footnotetext{
${ }^{44}$ Por.: Tamże.

${ }^{45}$ M. Czuchnowski, Profil w złotych gałazkach, Tydzień Polski 1967 nr 18.

${ }^{46}$ J. Surynowa-Wyczółkowska, Ostatnia ksiażka Herminii, Tydzień Polski 1967 nr 27.

${ }^{47}$ Istnieje problem z klasyfikacją gatunkową ostatniego z tekstów. Bowiem stosunkowo obszerne wspomnienie Janiny Surynowej-Wyczółkowskiej o autorce Wierności życiu poprzedziło właściwą, acz niezbyt rozbudowaną recenzję tego utworu. Sam tytuł wskazuje także na to, że w zamyśle miała to być recenzja (Ostatnia ksiażka Herminii). Ten tekst w nieco zmienionej postaci, m.in. bez fragmentu omawiającego Wierność życiu Janina Surynowa-Wyczółkowska opublikowała w londyńskim „Głosie Kobiet” (1973 nr 72, s. 13-15), w cyklu „Sylwetki”.

${ }^{48}$ Nazwisko Naglerowej kilkakrotnie pojawia się w innej książce wspomnieniowej Edwarda Kozikowskiego Od Prusa do Gojawiczyńskiej, Warszawa 1969 (np. s. 333.

${ }^{49}$ M. Danilewicz Zielińska, Fado o moim życiu. Rozmowy z Włodzimierzem Paźniewskim,

${ }^{50}$ Tadeusz Nowakowski wspominając „twarze” tych, których spotkał, w ironicznie określanym przez niego „Domu Smutku Polskiego” w Londynie, emigrantów zmarłych na obcej ziemi, przywołuje i Herminię Naglerową; por.: T. Nowakowski, O Stefanii Zahorskiej. „...Aż po daleki wygnańczy grób”, [w:] tegoż, Aleja dobrych znajomych, Londyn 1968, s. 153.

51 J. Czapski, Na nieludzkiej ziemi, Kraków 2001, s. 310-311. Czapski wspomina Naglerowă pracującą w dziale wydawniczym i bibliotecznym w Jungi-Jul pod Taszkientem, w Armii Polskiej w ZSRR, pod dowództwem gen. Andersa.

52 Głuchowski, wspominając życie w „polskim Londynie”, odnotowuje „,́lady” obecności autorki Ludzi sponiewieranych. Wynajmuje bowiem pokój u Józefa Zielickiego, w którym nie-
} Toruń 2000. 
Każdy ze wspominających — na co już zwracałam uwagę — w nieco inny sposób buduje portret pisarki, koncentrując się na różnych aspektach jej biografii. Wspomnienia Edwarda Kozikowskiego przywołują wspólną z Naglerową (wówczas początkującą poetka) przynależność do „Gospody Poetów”, którą to nazwą określano zarówno grupę, jak i pismo, a później kolejno wydawane pismo literackie „Ponowa”, a także ich współpracę w zarządzie Związku Zawodowego Literatów w Warszawie. Natomiast Marian Czuchnowski, Janina Surynowa-Wyczółkowska wspominają Naglerową jako pisarkę już ukształtowaną, znaną, aktywną. Ukazują ją w różnorodnych sytuacjach i okolicznościach: jako uczestniczkę zjazdu delegatów Związku Literatów w Krakowie w 1932 roku (Czuchnowski), w warszawskiej redakcji „Bluszczu”, goszczącą wraz z kobietami artystkami, pisarkami u pani prezydentowej Mościckiej na Zamku, w literackich salonach Warszawy (Surynowa-Wyczółkowska). Poza tym, dzieląc z nią los wychodźczy, przywołują epizody z życia na emigracji.

Autorzy omawianych tekstów posługują się podobną strategią, jak Naglerowa we Wspomnieniach o pisarzach, a więc odtwarzają bezpośrednie spotkania, które zapadły w ich pamięć, przybliżają jej sylwetkę opisując wygląd zewnętrzny. W analizowanych szkicach Mariana Czuchnowskiego, Janiny Surynowej-Wyczółkowskiej, Edwarda Kozikowskiego odnajdujemy opisy wyglądu zewnętrznego pisarki zapamiętanej z lat 30. W rekonstruowanym portrecie jawi się jako osoba niewielkiego wzrostu, drobna, ubrana elegancko, acz w sposób, który nie wyróżniał jej z otoczenia (ciemne suknie, które zdobi koronka, broszka, kamea). Uwagę opisujących zwracały oczy. Przez Surynową-Wyczółkowską określone jako ,żywe”,53, w szkicu Kozikowskiego „,w czarnej oprawie rzęs czarowały spojrzeniem ujmującym i pełnym wdzięku" "54, u Czuchnowskiego „,pełne ciekawości" ${ }^{\text {"55 }}$. Dopełnieniem tych opisów jest relacja Zofii Kozarynowej, która Herminię Naglerową poznała dopiero w Londynie w 1951 roku. Oto jak zapamiętała autorkę Ludzi sponiewieranych:

[...] widocznie wyobrażałam ją sobie — na zasadzie jej stanowiska w literaturze i wybitnej roli w kobiecej służbie wojskowej — jako tęgą i pewną siebie panią, przemawiającą władczo i z wysoka. Ujrzałam natomiast drobne chucherko z dużymi, jasnymi oczami i wesołym uśmiechem, w twarzy starzejącej się, ale jeszcze pełnej wdzięku $^{56}$.

Tymon Terlecki, we wstępie do Wierności życiu charakteryzując pisarkę stwierdził: „Naglerowa «przedwojenna» była panią z dobrego towarzystwa i literatką. Była konwencjonalnie mieszczańska i jakby tylko stylizowała się na artystkę" ${ }^{, 57}$. Z tymi opiniami polemizowała Janina Surynowa-Wyczółkowska, wspominając autorkę Krauzów

gdyś mieszkała pisarka. Owe ,ślady” to „biureczko georgiańskie, z nogami skróconymi kiedyś dla pani Herminii Naglerowej, aby mogła wygodnie pisać”, gdyż jak wiemy, była osobą drobną, niewielkiego wzrostu; por.: K. Głuchowski, W polskim Londynie 1947-1970, Londyn 1999, s. 81,264

${ }^{53}$ J. Surynowa-Wyczółkowska, Ostatnia ksiażka Herminii...

${ }^{54}$ E. Kozikowski, Herminia Naglerowa..., s. 201.

${ }^{55}$ M. Czuchnowski, Profil w ztotych gałazkach...

${ }^{56}$ Z. Kozarynowa, Pani Herminia...

${ }^{57}$ T. Terlecki, O Herminii Naglerowej $i$ „,Wierności życiu”, [w:] H. Naglerowa, Wierność życiu, Londyn 1967, oprac. i wstęp T. Terlecki, s. 8. Tekst o Herminii Naglerowej zamieszczony został w książce: T. Terlecki, Spotkania ze swoimi, red. J. Degler, Wrocław 1999. 
i innych jako osobę bezpretensjonalną i miłą ${ }^{58}$. Podobnie Marian Czuchnowski pisał po latach o „bardzo dobrej, bardzo mądrej, bardzo skromnej pani",59.

Edward Kozikowski jako znajomy pisarki z okresu międzywojennego, współpracujący z nią także w zarządzie Związku Zawodowego Literatów w Warszawie, którego był sekretarzem, wspomina jej liczne przymioty. Oto jak charakteryzuje autorkę Matowej kresy:

Usposobienie miała pogodne, uśmiech prawie nie schodził z jej ust. [...] Była człowiekiem zrównoważonym i opanowanym. Nie pamiętam, aby kiedykolwiek dała się ponieść nerwom, zawsze wprowadzała nastrój harmonii i zgody. W dyskusji umiała panować nad tematem, w wywodach była niezwykle logiczna, obca jej była wszelka chaotyczność, zarówno w rozumowaniu, jak i w pracy... ${ }^{60}$.

Równie korzystna ocena dotyczyła relacji z innymi ludźmi cytowany już wielokrotnie Edward Kozikowski, stwierdza, że „zawsze starała się usprawiedliwić postępowanie, najzagorzalszego nawet adwersarza"61. Wyeksponowanie tych cech charakteru tłumaczy nam czytelnikom jej stosunek do portretowanych przez nią samą literatów. Marian Czuchnowski tak o tym pisał:

Ile razy zaglądałem do [...] tomu Wspomnień o pisarzach [...] zawsze myślałem o Herminii Naglerowej, że chciałbym kiedyś o niej napisać tak jak ona potrafiła pisać o pisarzach, których nie tylko lubiła jako twórców, ale także jako dobrych ludzi ${ }^{62}$.

Natomiast autorzy wspomnień, utrwalający emigracyjny portret autorki Ludzi sponiewieranych (Maria Danilewicz Zielińska, Zofia Kozarynowa, Janina Surynowa-Wyczółkowska) akcentują rys tragizmu, cierpienia, samotności, jakim naznaczyły pisarkę wojenne przeżycia, a więc więzienia i łagry, utrata męża, który zaginął aresztowany przez NKWD w 1939 roku, w którego śmierć, jak konstatuje Maria Danilewicz Zielińska, pisarka „nie chciała uwierzyć”, żyjąc ze „skrytą nadzieją odnalezienia męża”,63. Mimo tych dramatycznych doświadczeń zawsze przedstawiana jest jako osoba zaangażowana i aktywnie działająca, w Armii Polskiej na Wschodzie, we Włoszech, a później w Londynie w ZPPnO, jako osoba, której, jak wspomina Surynowa-Wyczółkowska, „los nie złamał, a jedynie ugiął"64. W relacjach z ostatnich dni pisarki i pogrzebu najbardziej dojmującym obrazem jest ,tragiczna samotność”, brak najbliższej rodziny, której nie mogli zastąpić pisarce otaczający ją życzliwi ludzie.

Podsumowując rozważania o wspomnieniach, o ich autorach i bohaterach warto przywołać społecznie aprobowaną zasadę, która, według wielokrotnie cytowanego tu Janusza Sławińskiego, polega na tym, że: „Sam akt wspominania publicznego zakłada akceptację osoby wspominanej" ${ }^{65}$. Przyjęcie takiego założenia sugeruje, że pozytywny

58 Oto charakterystyka autorki Krauzów zawarta we wspomnieniu Janiny Surynowej-Wyczółkowskiej: „,[...] była uprzejma, bardzo przyjacielska i zajęła się mną bardzo mile”; J. Surynowa-Wyczółkowska, Ostatnia ksiqżka Herminii...

${ }_{59}$ M. Czuchnowski, Profil w złotych gatazkach...

${ }^{60}$ E. Kozikowski, Herminia Naglerowa..., s. 201-202.

${ }^{61}$ Tamże, s. 202.

${ }^{62}$ M. Czuchnowski, Profil w ztotych gałazkach...

${ }^{63}$ M. Danilewicz Zielińska, Szkice o literaturze emigracyjnej, Wrocław 1992, s. 247; taż, Suplement. Znałam ich dobrze..., [w:] tejże, Fado o moim życiu..., s. 87.

${ }^{64}$ J. Surynowa-Wyczółkowska, Ostatnia ksiqżka Herminii...

${ }^{65}$ J. Sławiński, Czas wspomnień..., s. 162. 
wizerunek Herminii Naglerowej ${ }^{66}$ utrwaliły na kartach wspomnień osoby ceniące ją jako pisarkę i człowieka, natomiast niechętne jej, żywiące jakieś urazy prawdopodobnie milczały.

„Czas wspomnień” trwa, więc ciągle pojawiają się nowe świadectwa, dokonuje się reinterpretacji biografii pisarki. Zamknie go dopiero fizyczny kres osób będących świadkami bądź uczestnikami życia autorki Ludzi sponiewieranych.

${ }^{66}$ Niewielką rysę na wizerunku Naglerowej jako człowieka stanowi informacja o niedostatecznej opiece po wojnie nad młodziutką Zofią Górską (później Romanowiczowa); por.: Przypadek czyli prawdziwa fikcja. Z Zofia Romanowiczowa rozmawia Stanistaw Bereś, Fraza $2000 \mathrm{nr}$ 3(29), s. 109. Pisze o tym także A. Jamrozek-Sowa, Życie powtórzone. O pisarstwie Zofii Romanowiczowej, Rzeszów 2008, s. 404. 